\title{
THE ORIGIN OF AN OFFICIAL TURKIC STYLE AND ITS PLACE IN THE DEVELOPMENT OF A WRITTEN LITERARY LANGUAGE
}

\section{Qudratulla Sharipovich Omonov}

Doctor Of Philology, Professor, Tashkent State University Of Oriental Studies, Tashkent, Uzbekistan

Gulchekhra Shavkatovna Rikhsieva

Doctor Of Philosophy In Philological Sciences, Associate Professor, Tashkent State University Of Oriental Studies, Tashkent, Uzbekistan

\section{Nadira Tashmirzaevna Khalmurzaeva}

Doctor Of Philosophy In Philological Sciences, Associate Professor, Tashkent State University Of Oriental Studies, Tashkent, Uzbekistan

\section{ABSTRACT}

The researchers who carry out their investigations on the history of stylistics, it is naturally interested in them in which stage of social development appeared an official style. In a define meaning the style of the documents - relate to appearing the history of statehood and legislative relations. We will be witness if we pay close attention to the essence of the problem that the official texts and their style is a very old social and linguistic phenomenon that passed deep stage by a stage development process. This process in the history of styles, from our viewpoint, started to form before appearing at the institutes of statehood. To prove this argument we rely on examples.

KEYWORDS: - Writing style, official Turkic style, written literary language, inscribed sign, plotted memory signs, bitim, yarliğ, historical narration.

\section{INTRODUCTION}

It is known, that when a human society appeared, people started to feel nature; started the process familiarization with the surrounding world. It was one of the main reasons for the development of artistic thinking. A striking example of artistic thinking is the pictures of different animals and plants were inscribed on caves, cliffs, and stones. It is appropriate, that it is impossible to identify when ended artistic thinking which was reflected on cliffs, caves and stone animals and plants and hunting process and when appeared writing style [Loukotka
$1950,14]$. In this stage of social development, it was necessary registration of mutual exchange, barter and economical relations of family, tribe and social members. This process connects with an official relation created appearing of registration. Registration (fixation) was an initial factor of appearing writing. This task (registration) was possible through establishing direct relation by members of tribe-people, but in this case, the weakness of human memory was the reason for forgetting many mutual exchanges. Time was the main obstacle for it; written, a registered word might prevail over it. It is not surprising that in our folklore the proverb "Fixed in letter - caught on fire" means it. 
CURRENT RESEARCH JOURNAL OF PHILOLOGICAL SCIENCES 2(8): 45-49,

May 2021 DOI: https://doi.org/10.37547/philological-crjps-02-08-11

ISSN 2767-3758

(C)2021 Master Journals

Crossref do: 81 Google

Accepted26 ${ }^{\text {th }}$ August, 2021 \& Published $31^{\text {th }}$ August, 2021

This wise word helps to understand that the registration, writing, and document is an old phenomenon of our nation.

Along with this, we will analyze the most ordinary form of official relation elements that were passed in a common form in the history of most ancient nations.

\section{THE MAIN FINDINGS AND RESULTS}

At first, signs invented by people were not for sending mind through distance or time, but just for reminding. It was the custom for remembering something knotted the tip of the headscarf. Later it was started to give a definite meaning to the things. It was considered unique signals and demanding signs of things were agreed before. Such a kind of sign was inscribed on a branch or trunk of the tree, knots, bindings, but during announcing of a war it was used an arrow and other things. Such kind of style was named "a thing with inscription" that was used for attaching the meaning to the thing [Drachuk 1980, 11]. It is possible to see clearly "a thing with inscription" the sign of an official style in the period of development of society. For example, for notification of amount, numbers were inscribed demanded signs on board. These branches were used for concluding agreements. For composing agreement the branch was divided into two parts, one part on one side, the second part on another side. When the parts were connected inscriptions were combined. Such a kind of branch was used for composing a dept agreement instead of receipt. To keep in mind necessary for a long time it was also used branches for events lever.

Researches which were made in a field of history origination of writings "information sticks or canes" were used in ancient time as a messenger. It was popular among European nations, China, Australian and African tribes. An envoy of another tribe who brought cane was used as a document that proves the authority of the person (was used as "credentials" given to envoys). On the cane was an inscribed sign and plotted memory signs. The envoy when he looked at that he could remind how many tasks were given to him. Placing of inscriptions-signs had definite conditional meanings.

Official relations among the oldest nations of the world were analyzed above examples relate to the development of signs we can find in the history of Turkic nations too. Such a kind of example we can come across in one event related with old ancestors of Turkic nations Scythian which was written in the fourth book by a Greek traveler and historian Herodotus's work History. That historical event was narrated by Herodotus in such a way: Persian shah Darius I ascended on the throne, after punishing those who did not subordinate to him, he immediately paid attention to the lands of neighboring nation.

Numerous troops of Darius I attacked the Scythian land.

After entering deeply in Scythian land Darius I was in trouble, the Scythian shah sent a strange gift to a terrible conqueror: a bird, a mouse, a frog, and five arrows. Although the Persians asked many times the meaning of the message from the messenger, he repeated one answer: it was ordered to him to give the "gift", to understand the meaning of it was granted to them.

Later it became clear, this gesture was severe demand (ultimatum): "If, you, Persians, do not fly like a bird and fade away, or like a mouse does not enter under the ground, or like a frog does not dive in swamp, in that case, you will be wounded from these arrows and stay in these lands".

An unexpected situation happened. Darius I the shah of the greatest empire in the world of that period was disgracefully defeated. Creators of "thing" ultimatum - won Scythians [This given example from the registered book of Drachuk: Drachuk 1980, 35-36].

The facts about the signs of development of official relations of Turkic nations could be traced back in the ancient period like ancient Egyptians, Sumerians, Chinese, Indians, and Persians. 
CURRENT RESEARCH JOURNAL OF PHILOLOGICAL SCIENCES 2(8): 45-49,

May 2021 DOI: https://doi.org/10.37547/philological-crjps-02-08-11

ISSN 2767-3758

(C)2021 Master Journals

\section{Crossref do: 81 Google}

Accepted $26^{\text {th }}$ August, 2021 \& Published $31^{\text {th }}$ August, 2021

Necessity in official papers rose because socialeconomical relations were getting more complicated. Distribution of a job and a good exchange demanded a definite calculation.

All these processes created the basis for the gradual development of official relations. So, it means that it was one of the factors of appearing in writing in official thought.

Official relation - is an important proof of stepping in the developing stage of spreading in different tribefamilies as people.

The different genres of the documents appeared because of the needs of social development. Therefore, among the main part of written sources which came to us from the ancient time of history of humanity were different documents comparatively with literary, historical and scientific works.

Literary language is an improved form of folk language and one of the forms which could be used in official relations, state ruling, mass media, and education system. Comparatively, with a folk language, it appeared in a more developed period of progress in society. Origination of the education field was the reason for the rising of literacy, development of the nation's cultural view, in terms of strengthening the norms of literary language.

It is known, that a literary language has appeared in connection with a written form of literature. But, the history of a literary language should not be bound with a written form of literature. In terms of appearing a written form of literature, one can see the influence of other styles on the origination of a literary language. Particularly, the influence of the official style was great in this process.

The history of an official style relates to the history of statehood and international relations. In the state ruling processes, official texts were used in relations with neighboring states were put in a certain covered form; it was produced diplomatic terms, forms of appeal, phrases and depiction styles. Even the text documents which are used for different purposes differ from each other. It means that the official style of letter appeared before forming a literary language.
Exactly, an early form of Turkic literary language was in the form of official language.

In the period of forming a written literary language, the style of official texts was more developed. The phrases, depiction style and official terms used in documentation language in completed form were moved into a literary language and naturally, this process stimulated to put it in a definite form. For example, it became clear that the words bitim and yarliğ were used in official appeal at the same time when documentation has appeared. Their meanings also stick to: bitim - means "an agreement document in a written form", but yarlïg - means "a written decree, an order". Before appearing administrative form of official relations between two people goods exchange, mutual exchange, it is obvious that the word tanuq (witness) was not created. Later these words were accepted into a literary language with its form and meaning. Such an event may observe in depiction forms. Thus, a literary language will base its tradition on composing of official texts next stage of its development

For example, such a kind of process was started in the history of Turkic language in the V-VI centuries. We can observe the influence of traditions of writing the chronicles and official style on rising of old Ko'k Turkic language of written relics. Later this language was the reason for the origination of all Turkic literary languages and the rising tradition of text composing.

When inscriptions were investigated these historical works were created in a literary language that was figured out by scholars. But, a literary style in inscriptions was not the only factor of appearing of a literary language. The following observations became clear that the influence of the official text's style was great on the appearance of Turkic literary language. For example, Q.Sodiqov in one of his articles that were devoted to the roots of documentation during analyzing the text structure of urhun inscriptions pays closely our attention to the origin of the texts. According to his viewpoint, these origins were the part of the official style which was taken from the 
CURRENT RESEARCH JOURNAL OF PHILOLOGICAL SCIENCES 2(8): 45-49,

May 2021 DOI: https://doi.org/10.37547/philological-crjps-02-08-11

ISSN 2767-3758

(C)2021 Master Journals

Crossref dof 81 Google

Accepted $26^{\text {th }}$ August, 2021 \& Published $31^{\text {th }}$ August, 2021

appeal of the ruler to the nation. Such a kind of origin usually comes before official texts. The rulers inscribed their credentials in the exact form of origins [Sodiqov 1998, 31].

It is important, that composing tradition of the text in inscriptions were formed long ago. It became clear, that Great Ko'kTurkics learned the sample of writing introductions in their inscriptions from ancient ancestors of the oldest Turkic nations. According to the ancient Chinese sources, such a kind of form of origins could come across in the II century B.C in correspondence of ancient Turkic states which were sent to Chinese [Bernshtam 1940, 70] ${ }^{1}$. This information proves that the place of official texts and the style of chronicles were great in appearance and development of ancient Turkic literary language, particularly, appearance the language of Ko'k Turkic inscriptions.

It should be noted, that the method and experiences which were used in the process of creating a literary language of ancient Turkic nations were substantiated. The stage in which Turkic literary language passed in its processes of development we can see in the history of other literary languages too.

If we observe the history of forming the literary norms of other languages of the world we shall comprehend that the place of official style was great [Koduhov 1974, 187]. It should be noted, that the phenomena which were observed in the history of ancient Turkic literary language, was repeated later in the XV-XVI centuries just in the same form in the history of Russian literary language.

The official style was one of the main factors of appearing literary language in the history of the Russian language. Official texts of Kyiv Russia were in the form of credentials, agreement and state laws ("Russia true"). The documentation tradition of Kyiv

${ }^{1}$ In the chapter "The norms of written official style and their choosing" of monograph in part of "The phrases (stereotype) which were formed in official texts and their place in supplying formality of the text" widely discuses such a kind of form of origins.
Russia later continued in Moscow Russia too. After strengthening the state and ruling policy of the whole Russian state was used this language in correspondences. Together with this, it was getting to appear in the Russian literary language. The early formation of the written form of Russian literary language started in the XV-XVI centuries. This process, by itself, relates to the evolution of official texts and the style of inscription of chronicles (historical narration историческое повествование). Such a kind of situation we can observe in the history of German literary language [Koduhov 1974, 191].

The appearance of literary languages sometimes happens in resembling each other condition. It comes to conclusion, the experiences which were collected by our ancestors might influence on other nations too. Maybe, it is a common rule of appearing literary languages. Anyway, in the history of ancient Turkic literary language was chosen the right way.

\section{Conclusion}

Generally, in the period of formation of the written form of a literary language the signs of official relations and its style were formed long ago, it was in the stage of development. The written form of a literary language continued its way in a new form which was related to a tradition of composing official texts. The main concept, term and ready phrases used in documentation language were adapted to a literary language. Thus, the names of concepts related to social relations, amount, number, year, and the names of titles, the names of the documents, different measures and weight were taken from the documents should be registered as an ancient section of literary language. That is to say, the finished form of documentation language moved to the ancient section of literary language. The official style was the basis of the formation of the literary language. Everything noted allows saying that the official language was an ancient style of writing. 
CURRENT RESEARCH JOURNAL OF PHILOLOGICAL SCIENCES 2(8): 45-49,

May 2021 DOI: https://doi.org/10.37547/philological-crjps-02-08-11

ISSN 2767-3758

(C)2021 Master Journals

Crossref do: 81 Google

Accepted26 ${ }^{\text {th }}$ August, 2021 \& Published $31^{\text {th }}$ August, 2021

\section{REFERENCES}

1. Омонов, К. Ш., \& Жанзакова, М. А. (2020). РУХАНИ ЖАНҒЫРУ-ЕЛ ДАМУЫНЫҢ БАСТЫ ҚАҒИДАСЫ. Qazaqtaný, (5), 111115.

2. Nasirova, S. A., Hashimova, S. A., \& Rikhsieva, G. S. (2021). THE INFLUENCE OF THE POLITICAL SYSTEM OF CHINA ON THE FORMATION OF SOCIAL AND POLITICAL TERMINOLOGY. Journal of Central Asian Social Studies, 2(04), 10-17.

3. Mirzakhmedova, K. V. (2021). Comparative Analysis of General Words-Terms In Persian and Uzbek Languages. Psychology and Education Journal, 58(1), 1050-1056.

4. Ashiralievich, VA va \& Vasilovna, MK (2020). Sharq tillarini o'rganishning interaktiv vositasi. Osiyo ko'p o'lchovli tadqiqot jurnali (AJMR) , 9 (3), 78-86.

5. Hashimova, S. A., \& Nasirova, S. A. (2021). FEATURES OF FORMING OF ANIMATED NOUNS WITH THE AFFIXES IN MODERN CHINESE LANGUAGE. Journal of Central Asian Social Studies, 2(04), 1-10.

6. Халмурзаева, Н. Т. (2020). ТИПология ЯПОНСКОГО КОММУНИКАТИВНОДЕЛОВОГО ЭТИКЕТА. Вестник науки и образования, (14-2 (92)).

7. Рихсиева, Г. Ш. (2014). ОЛИЙ ТАЪЛИМ МУАССАСАЛАРИ РЕЙТИНГИ-СИФАТ ВА ТАРАҚҚИЁТ ОМИЛИ. Oliy ta'lim taraqqiyoti istiqbollari $=$ Perspectives of higher education development $=$ Перспективы развития высшего образования: То 'plam № 2/ma'sul muharrir MA Rahmatullayev.Издательство: Vita Color T.: 2014.-161 b., 29.

8. Omonov, Q. S. (2019). THE WAYS OF OFFICIALISATION OF THE DOCUMENTS AND THE PROBLEM OF LEGITIMIZATION OF THE TEXT. Научные вести, (7), 43-51.
9. AMANOV, K. (2015). THE MATTER OF DIVIDING AGES IN HISTORY OF TURKIC OFFICIAL METHOD. Turkish Studies (Elektronik), 10(12), 57-68.

10. Mirzaxmedova, H. (2020). TERMS MADE FROM THE ORIGINAL IRANIAN VOCABULARY IN PERSIAN. Philology Matters, 2020(1), 137-145.

11. Омонов, К. Ш. (2015). Типы деловых документов в истории старотюркского литературного языка. Paradigmata poznani, (3), 71-74.

12. Mirzakhmedova, H. V., Omonov, K. S., \& Khalmurzaeva, N. T. (2021). METHODS OF IMPROVING LANGUAGE SKILLS USING MEDIA SOFTWARE. Journal of Central Asian Social Studies, 2(03), 47-55. 